\title{
Avaliação in vitro do papel do zinco no mecanismo de adesão de Escherichia coli em suínos
}

\author{
In vitro avaliation of zinc in the Escherichia coli adhesion
}

\author{
Álvaro Menin ${ }^{1}$, Gisele Branco ${ }^{2}$, Sandra Ferraz ${ }^{3}$ \& Eliana Knackfuss Vaz ${ }^{4}$
}

\begin{abstract}
RESUMO
Os distúrbios gastrintestinais e toxi-infeciosos causadas por Escherichia coli são uma importante causa de mortalidade, atrasos no crescimento e decréscimo na taxa de conversão alimentar em leitões no período pós-desmame, gerando perdas econômicas severas. Dentre as estratégias de combate a estas formas de apresentação estão à utilização de antimicrobianos, probióticos e aditivos na dieta, como o óxido de zinco. O zinco tem efeito promotor de crescimento, diminui a incidência de diarréia e mortalidade de leitões desmamados. O objetivo da realização desse trabalho foi verificar, in vitro, o papel de diferentes concentrações de zinco na adesão da $E$. coli aos enterócitos de suínos. O ensaio avaliou a eficácia de quatro suspensões: zero (controle negativo), 1200, 2400 e 3000 ppm de óxido de zinco. O teste de adesão fundamentou-se na exposição de enterócitos suínos, a uma cepa patogênica de $E$. coli e ao zinco, simulando o que ocorreria in vivo. Nas condições in vitro em que foi desenvolvido o experimento, o zinco não foi capaz de inibir a adesão de E.coli aos enterócitos em nenhuma das concentrações utilizadas.
\end{abstract}

Descritores: suínos, adesão, enterócitos, zinco.

\section{ABSTRACT}

The disturbances gastrointestinais caused by Escherichia coli are an important mortality cause, decrease the growth and the rate of alimentary conversion in pigs in the period post-weaning, causing severe economical losses. Among the strategies are antimicrobials use, probiotics and addictive in the diet, as the oxide of zinc. The zinc has effect as growth promoter, reduces the diarrhea incidence and mortality of weaned pigs. The aim of this study was to verify, in vitro, the role of different concentrations of zinc in the adhesion of the E. coli to the cells of intestinal wall of swine. This study evaluated the effectiveness of 4 suspensions: 0 (negative control), 1200, 2400 and 3000ppm of oxide of zinc. The adhesion test was based in the exhibition of the cells of intestinal wall to pathogenic strain of E. coli and to the zinc, simulating what happened in the intestine. In the conditions of that experiment, the zinc was not capable to inhibit the adhesion of E. coli to the cells of intestinal wall in none of the used concentrations.

Key words: swine, adhesion, enterocytes, zinc. 


\section{INTRODUÇÃO}

Os distúrbios gastrintestinais são resultados da intensificação da produção e falhas no manejo dentro da suinocultura [3]. A fase mais crítica para os leitões é o período pós-desmame, pois uma série de eventos estressantes atinge estes animais tornando-os predispostos a problemas entéricos $[2,15,19,23]$. As diarréias são as mais importantes causas de mortalidade, atraso no crescimento e decréscimo na taxa de conversão alimentar em leitões no período pós-desmame, gerando perdas econômicas severas $[13,18]$. Cepas patogênicas de Escherichia coli (E. coli) são associadas com quadros de diarréia por volta da terceira semana de vida (Colibacilose da terceira semana) e toxi-infecção (Doença do Edema) entre 4 e 15 dias pos desmame $[12,21]$. Em ambos os casos, para que ocorra o estabelecimento da patogenia, a $E$. coli precisa se aderir a receptores específicos presentes nos enterócitos da mucosa do intestino delgado, através de apêndices fimbriais protéicos, possibilitando a produção das toxinas específicas [3,5-8,21,24]. As estratégias de controle e prevenção englobam uso de antimicrobianos, probióticos, restrição alimentar e utilização de aditivos na dieta, como o óxido de zinco, fonte mais comum de zinco utilizada na suinocultura [2,9,22]. $\mathrm{O}$ zinco reduz a incidência de diarréia e a mortalidade causada por $E$. coli em leitões no período pós-desmame [2,4,11,13,17].

O objetivo deste trabalho foi verificar, in vitro, o papel de diferentes níveis de zinco na adesão da $E$. coli enterócitos de leitões.

\section{MATERIAIS E MÉTODOS}

Foram testados, in vitro, diferentes níveis de zinco (a partir do Óxido de Zinco) na inibição da adesão da $E$. coli aos enterócitos. O teste de adesão foi realizado expondo os enterócitos com seus receptores às bactérias e ao óxido de zinco, simulando o que ocorreria in vivo. $\mathrm{O}$ ensaio avaliou a eficácia de quatro suspensões diferentes de óxido de zinco em uma mistura padrão, contendo enterócitos e $E$. coli em albumina sérica bovina a $1 \%$. As suspensões utilizadas foram zero (controle negativo), 1200, 2400 e 3000ppm de óxido de zinco (puro para análise) em água destilada. Um leitão recém-nascido, antes da ingestão do colostro, para que não houvesse interferência da imunidade passiva, filhos de mãe com histórico de diarréia em leitegadas anteriores foi eutanasiado, e o intestino delgado foi coletado. Após ser congelado, uma porção de aproximadamente $20 \mathrm{~cm}$, foi cortada longitudinalmente e submergido em solução hipotônica de EDTA. Uma lâmina de vidro foi utilizada para remover as células intestinais que foram colocadas em $50 \mathrm{ML}$ da solução de EDTA fria, onde foram incubados por 30 minutos a $4^{\circ} \mathrm{C}$. A seguir, foi utilizado um gral para romper a estrutura do tecido e o homogeneizado foi filtrado em lã de vidro. Esta solução foi centrifugada a $1.200 \mathrm{~g} /$ 10 minutos $/ 4^{\circ} \mathrm{C}$. O pellet foi ressuspendido em $5 \mathrm{ml}$ de PBS fria com pH igual a 7,4. Após foi feita nova centrifugação a $1.200 \mathrm{rpm} / 10 \mathrm{~min} / 4^{\circ} \mathrm{C}$ e o pellet de enterócitos foi ressuspendido em $5 \mathrm{~mL}$ de PBS fria.

$\mathrm{O}$ teste de adesão foi realizado da seguinte maneira: $100 \mathrm{ml}$ do soro teste foi misturado com $10 \mathrm{ml}$ de cultura bacteriana de E. coli E68 $\left(1,5 \times 10^{8} \mathrm{CFU} / \mathrm{ml}\right)$. Após uma incubação de $45 \mathrm{~min} / 37^{\circ} \mathrm{C} / 50 \mathrm{rpm}$ em agitado orbital, foi adicionado $20 \mathrm{ml}$ da suspensão de enterócitos e novamente incubados a $15 \mathrm{~min} / 37^{\circ} \mathrm{C} / 140 \mathrm{rpm}$. Seguiram-se três centrifugações de $150 \mathrm{rpm} / 5 \mathrm{~min}$ e o pellet ressuspendido em igual volume de PBS pH 7,4. Foi feito um esfregaço e fixado pelo calor e corado com corante de Giemsa. A leitura foi feita com microscópio ótica e objetiva de imersão.

\section{RESULTADOS}

Os resultados foram obtidos pela avaliação microscópica das lâminas. Nestas, observou-se que a $E$. coli estava aderida na superfície das células intestinais, demonstrando que nenhuma das concentrações utilizadas (1200, 2400 e 3000 ppm de óxido de zinco) foi capaz de impedir esta adesão. $\mathrm{O}$ controle negativo, com albumina sérica bovina, mostrou o mesmo resultado, ou seja, a maioria das bactérias encontrava-se formando agregados na superfície dos enterócitos, evidenciando sua adesão.

Desta forma, fica demonstrado que, nas condições em que o teste foi realizado, o zinco nas concentrações utilizadas, não foi capaz de impedir a adesão da E.coli às células intestinais.

\section{DISCUSSÃO}

$\mathrm{O}$ fato das diferentes concentrações de zinco não impedirem a adesão da $E$. coli aos enterócitos pode estar relacionado à possibilidade do ambiente in vitro não estar simulando satisfatoriamente o que ocorre in vivo ou que o zinco interfira em outros mecanismos secretórios, por exemplo, da $E$. coli e não na adesão [2].

O modo de atuação do zinco na redução da incidência de diarréia e mortalidade por doença do edema ainda não é conhecida [2,20]. Pesquisas in vivo usando as quantidades de 2.400 a 3.000 ppm de zinco na dieta de leitões por 42 dias após o desmame indica- 
ram que o zinco tem efeito promotor de crescimento, atua beneficamente sobre o consumo de ração e reduz eficientemente a incidência de diarréia e mortalidade por colibacilose no período após o desmame [2,10,13, 14,17]. A adição de 2400 ppm na dieta de leitões após o desmame promoveu o aumento do ganho de peso e reduziu a incidência de diarréia, no entanto sua eficiência variou de acordo com o grau de pureza da fonte de zinco $[11,16]$.

A adição de diferentes níveis de zinco não foi eficiente para o controle da diarréia pós-desmame em leitões [1,18] e o uso na dieta de 3000 ppm de zinco no período de 21 a 42 dias após o desmame leva a sintomas de toxidez nos animais [2]. Além disso, questiona-se a inclusão de altas dosagens de zinco nas dietas, pois grande parte do zinco consumido na forma de óxido é excretada nas fezes, gerando poluição ambiental e consequiências graves para saúde pública [18].
Alguns autores sugerem que o zinco atua aumentando a concentração intestinal de $\operatorname{IgA}$ e com isso reduz a translocação de bactérias do interior do intestino para sítios extra-intestinais e diminui a multiplicação bacteriana [4]. A constante excreção da E. coli, associada à alta concentração de zinco nas fezes e baixa ocorrência de diarréia, indica que esse mineral não inibe a multiplicação da bactéria no intestino e sugere a existência de outros mecanismos de ação do zinco na prevenção da diarréia $[1,16]$.

\section{CONCLUSÕES}

Nas condições in vitro em que foi desenvolvido esse experimento, concentrações de óxido de zinco de 1200, 2400 e 3000 ppm, testadas, não inibiram a adesão de Escherichia coli aos enterócitos de suínos, sugerindo outros mecanismos de ação do zinco no desenvolvimento da patogenia da colibacilose.

\section{REFERÊNCIAS}

1 Arantes V.M., Thomaz M.C., Kronka R.N., Malheiros E.B. \& Ristow L.E. 2002. Níveis de zinco na dieta de leitões recémdesmamados sobre isolamento de E. coli. In: Anais do I Congresso Latino Americano de Suinocultura. (Foz do Iguaçu, Brasil). 1 CD-ROM.

2 Bertol T.M. \& Brito B.G. 1998. Efeito de altos níveis de zinco suplementar no desempenho e na mortalidade de leitões. Pesquisa Agropecuária Brasileira. 33: 451-459

3 Bertschinger H.U. \& Fairbrother J.M. 1999. Escherichia coli Infections. In: Straw B. E. D'Allaire, S. Mengeling, W.L. Taylor D.J. (Eds). Disease of Swine. 8th edn. Ames: Iowa State University Press, pp. 431- 468.

4 Broom L.J., Miller H.M, Kerr K.G. \& Knapp J.S. 2006. Effect of zinc supplemented as either an organic or an inorganic source and of microbial phytase on zinc and other minerals utilization by weanling pigs. Veterinary Science. 80: 45-54

5 Chae C., Cheon D.S., Min K., Kno, D. \& Lee Y.S. 1998. Edema disease: season al prevalence and O serogroup. In: Proceedings of the 15th Congress of the International Pig Veterinary Society. (Birmingham, England). p.103.

6 Cho W.S., Park Y.C. \& Chae C. 2000. Genotypic prevalence for fimbriae and entrotoxins in Escherichia coli isolated from diarrheic piglets in Korea. In: Proceedings of the 16th Congress of the International Pig Veterinary Society. (Melbourne, Australia). p.54.

7 Gyles C.L., Prescott J.F., Songer J.G. \& Thoen C.O. 2004. Pathogenesis of Bacterial Infections in Animals. 3th edn. Iowa: Blackwell Publishing, 456p.

8 Hampson D.J. \& Murdoch A.I. 2002. Chemeq polymeric antimicrobial for the control of experimental post weaning colibacilosis [paper 278]. In: Proceedings of the 17th Congress of the International Pig Veterinary Society. (Ames, Iowa).1 CD-ROM.

9 Johansen M., Jorgensen L. \& Hansen C.F.2000. Restricted feeding for prevention of $E$. coli associated diarrhea in weaned pigs. In: Proceedings of the 16th Congress of the International Pig Veterinary Society. (Melbourne, Australia). p.20.

10 Lima G.J.M.M., Guidoni A.L., Mores N., Bertol T.M. \& Gil L.G.V. 1996. Efeito do uso de diferentes fontes de óxido de zinco em dietas de leitões após o desmame. In: Resumos da XXXV Reunião Anual da Sociedade Brasileira de Zootecnia. (Fortaleza, Brasil). pp.177-181.

11 Lima G.J.M.M., Guidoni A.L., Mores N., Bertol T.M. \& Gil L.G.V. 1996. Efeito do uso de altos níveis de zinco em dietas simples e semi complexas de leitões após o desmame. In: Resumos da XXXV Reunião Anual da Sociedade Brasileira de Zootecnia. (Fortaleza, Brasil). pp.185-187.

12 Mattsson S. \& Wallgren P. 2000. Phenotyping of E. coli serotypes associated to oedema disease. In: Proceedings of the 16th Congress of the International Pig Veterinary Society. (Melbourne, Australia). p.51. 
13 Melin L., Holmgren N., Wallgrean P. \& Franklin A. 1998. Sensitivity toolquindox and zinc oxide in coliform bacteria from weaned piglets. In: Proceedings of the 15th Congress of the International Pig Veterinary Society. (Birmingham, England). p.213.

14 Miyada V.S., Menten J.F.M., Botelho F.G.A. \& Debuschi F. 1996. Efeitos de níveis de zinco dietético suplementar e períodos de fornecimento sobre o desempenho de leitões em recria. In: Resumos da XXXV Reunião Anual da Sociedade Brasileira de Zootecnia. (Fortaleza, Brasil). pp. 113-115.

15 Mores N. \& Amaral A. L. 2001. Patologias associadas ao desmame. In: Resumos do X Congresso Nacional da Associação Brasileira de Veterinários Especialistas em Suínos. (Porto Alegre, Brasil). pp. 215-224.

16 Mores N., Cristani J., Piffer I.A., Barioni W.J. \& Lima G.M.M. 1998. Efeito do óxido de zinco em leitões infectados experimentalmente com Escherichia coli. Arquivo Brasileiro de Medicina Veterinária e Zootecnia. 50: 513-523.

17 Paseka A., Smola J., Novotny L. \& Drabek J. 2004. The effect of administration of protected zinc oxide on diarrhea occurrence in post-weaning piglets. In: Proceedings of the 18th Congress of the International Pig Veterinary Society. (Hamburg, Germany). p.761.

18 Pejsak Z., Markowska L.D., Mokizycka A. \& Szkoda J. 1998. The effects of zinc supplementation on pig productivity and zinc concentration in tissues. In: Proceedings of the 15th Congress of the International Pig Veterinary Society. (Birmingham, England). p.17.

19 Rantzer D. \& Svendsen E. 2002. E. coli associated post weaning diarrhea in pigs: Effects of frequent feeding [paper 383]. In: Proceedings of the 17th Congress of the International Pig Veterinary Society. (Ames, Iowa).1 CD ROOM.

20 Revy P.S., Jondreville C., Dourmad J.Y. \& Nys Y. 2004. Effect of zinc supplemented as either an organic or an inorganic source and of microbial phytase on zinc and other minerals utilization by wealing pigs. In: Animal Feed and Technology. (Davis, EUA). 116: 93-112.

21 Sobestiansky J., Barcellos D., Mores N., Carvalho L.F. \& Oliveira S. 2001. Clínica e Patologia Suína. 2 ed. Goiânia: Art3, $464 \mathrm{p}$.

22 Tsiloyannis V.K., Kyriakis S.C., Vlemmas J. \& Sarris K. 1998. The effect of organic acids on the control of post weaning diarrhea syndrome of piglets. In: Proceedings of the 15th Congress of the International Pig Veterinary Society. (Birmingham, England). p.151.

23 Tsiloyannis V.K., Kyriakis S.C., Vlemmas J. \& Sarris K. 1998. The effect of organic acids on the control of post weaning oedema disease of piglets. In: Proceedings of the 15th Congress of the International Pig Veterinary Society. (Birmingham, England). p.152.

24 Wittig W. 1999. Infecções por Escherichia coli. In: Beer J. (Ed). Doenças infecciosas em animais domésticos. São Paulo: Roca, pp. 93-111. 